\title{
LOGICAL REASONING ANALYSIS BASED ON HIPPOCRATES PERSONALITY TYPES
}

\author{
Nurdin $^{1)}$, Ita Sarmita Samad ${ }^{2)}$, Sardia $^{3)}$ \\ STKIP Muhammadiyah Enrekang, Indonesia \\ enambelasnurdin@gmail.com ${ }^{1)}$; itaneverindita@gmail.com ${ }^{2)}$; sardiasaena@gmail.com ${ }^{3)}$
}

\begin{abstract}
The theory distinguishes human based on four different personality types such as: sanguine, choleric, melancholic, and phlegmatic. Different types of personality caused by differences in the dominant fluid in the body. These differences will result in terms of behavior, ways of thinking and to get along. The type of this research that is descriptive qualitative which it is describing the logical reasoning based on Hippocrates personality types. The logical reasoning is analyzed through the four types of personality in relation to mathematical problem solving. The Analysis is done based on the logical reasoning indicator/ subindicator and the steps of problem solving stated by Polya. The result shows that there is a reasoning difference on each type of personalities. The difference can be terms of the strenght or the weakness. Sanguine is quicker in understanding problems and communicating results, choleric is more accelerated in work, melancholic is more perfect at work, and phlegmatic is superior in terms of accuracy.
\end{abstract}

Keywords: Logical reasoning, Hippocrates, sanguine, choleric, melancholic, phlegmatic

Ungkapan seperti "Dia sangat sulit untuk berubah" atau "Dia paling suka bicara" sering digunakan untuk mendeskripsikan kepribadian sesorang. Menurut psikolog Kelly, kepribadian terdiri dari berbagai konstruksi mental yang melaluinya setiap orang memandang kenyataan. Berbagai ahli telah berusaha meneliti dan mencari unsur-unsur yang menyusun kepribadian seseorang. Salah satu teori kepribadian yang sangat terkenal adalah teori kepribadian Hippocrates. Menurut Hippocrates kepribadian seseorang ditentukan oleh jenis cairan yang dominan dalam tubuhnya. Cairan tersebut adalah sanguis, chole, melanchole dan phlegma. Abraham (2007:17) menjelaskan bahwa kepribadian adalah pola-pola pemikiran, perasaan dan perilaku yang tertanam dalam-dalam dan relatif permanen.

Akhir-akhir ini berbagai penelitian berusaha mencari hubungan antara beberapa cabang ilmu dan tipe kepribadian. Diantaranya Nurdin (2019, P.78), menemukan turunan sifat-sifat kepribadian dalam memecahkan masalah matematika. Nurdin (2015, P.14-19), menemukan perbedaan kempuan verbal dan kemampuan penyesuaian diri antara tipe kepribadian sanguinis dan koleris.[Emanual, p.8] These tendencies may, in some small way, lead to a better understanding of the connections between personality type and communication style. Specifically, this study explores whether someone who has a particular personality type also has a corresponding logical reasoning. Secara khusus, penelitian ini menganalisis apakah seseorang yang memiliki tipe kepribadian tertentu juga memiliki penalaran logis yang besesuaian.

\section{PERSONALITY TYPE}

Kepribadian (personality) adalah suatu istilah yang mengacu pada gambarangambaran sosial tertentu yang diterima oleh individu dari kelompoknya atau masyarakatnya. Kepribadian juga sering dihubungkan dengan ciri tertentu yang menonjol pada diri individu, oleh karena definisi kepribadian menurut pengertian sehari-hari 
menunjuk pada bagaimana individu tampil atau menimbulkan kesan bagi individu-individu lainnya (Sjarkawi: 2009).

(Kuntjojo:2009) Kepribadian (personality) merupakan salah satu kajian psikologi yang berdasarkan pemikiran, kajian atau temuan-temuan (hasil praktik penanganan kasus) para ahli. Objek kajian kepribadian adalah "human behavior", perilaku manusia.

Menurut Hippocrates (Suryabrata, 2012, P:79) tipe kepribadian atas dasar cairan yang mengalir dalam tubuh manusia terbagi empat tipe yaitu sanguinis, koleris, melankolis, dan, plegmatis. Tipe Kepribadian Hippocrate secara garis besar digambarkan dalam tabel berikut:

Tabel 1. Tipe Kepribadian menurut Hippocrates

\begin{tabular}{lll}
\hline $\begin{array}{c}\text { Cairan badan } \\
\text { yang dominan }\end{array}$ & Tipe & \multicolumn{1}{c}{ Sifat-sifat khas } \\
\hline Sanguis & Sanguinis & $\begin{array}{l}\text { Hidup, mudah berganti haluan, ramah, lekas } \\
\text { bertindak tapi lekas berhenti }\end{array}$ \\
\hline Chole & Koleris & $\begin{array}{l}\text { Hidup, penuh semangat, keras, daya juang } \\
\text { besar, hatinya mudah terbakar, optimis }\end{array}$ \\
\hline Melanchole & Melankolis & $\begin{array}{l}\text { Mudah kecewa, daya juang kecil, muram, } \\
\text { pesimistis }\end{array}$ \\
\hline Phlegma & Plegmatis & $\begin{array}{l}\text { Tidak suka terburu-buru, tenang, tidak mudah } \\
\text { terpengaruh, setia }\end{array}$ \\
\hline Sumber Suryabrata
\end{tabular}

Sumber: Suryabrata, 2012.

Menurut (Littauer :2008) ada empat tipe kepribadian dasar manusia yang membentuk karakter seseorang sebagai berikut:

1) Sanguinis (esktrovert, pembicara, optimis)

Kepribadian sanguinis cenderung disenangi oleh orang lain dan menjadi pusat perhatian, serta senang aktivitas kebersamaan yang menyenangkan. Kekuatan sifat sanguinis antara lain: suka bicara, secara fisik mempesona, emosional, demonstratif, antusias, kreatif, inovatif, ekspresif, penuh rasa ingin tahu, dan ingatan kuat untuk warna, mudah berteman dan menyukai orang lain, menyenangkan dan dicemburui orang lain, mudah memaafkan, mengambil inisiatif, menghindar dari hal-hal atau keadaan yang membosankan, dan menyukai hal-hal yang spontan.

Sanguinis mempunyai kelemahan sifat: sedikit pelupa, berpikir pendek, sulit berkonsentrasi, hidupnya serba tidak beratur, cepat bosan, suara dan tertawa yang keras, susah untuk diam, dikendalikan oleh keadaan atau orang lain. Dalam bekerja lebih suka bicara, mudah berubah pikiran, mendominasi percakapan, suka menyela dan susah mendengarkan dengan tuntas, dan egois.

2) Koleris (ekstrovert, pelaku, optimis).

Ciri-ciri Sifat koleris : Suka sekali mengatur orang. Ia tak ingin ada penonton dalam aktivitasnya, bahkan tamu pun bisa saja ia 'suruh' melalukan sesuatu untuknya. Akibat sifatnya yang 'bossy' itu membuat banyak orang koleris tak punya banyak teman. Orangorang berusaha menghindar dan menjauh agar tak jadi 'korban' karakternya yang suka 'ngatur' dan tak mau kalah itu.Senang dengan tantangan, suka petualangan. Tegas, kuat, cepat dan tangkas dalam mengerjakan sesuatu

Kelemahan korelis : Tidak sabar dan cepat marah, terlalu bergairah dan susah untuk santai, menyukai kontroversi dan pertengkaran, terlalu kaku dan kuat/ keras, tidak suka yang bertele-tele / terlalu rinci, sering membuat keputusan tergesa-gesa, memanipulasi dan menuntut orang lain, cenderung memperalat orang lain, menghalalkan segala cara demi 
tercapainya tujuan, workaholics (kerja adalah "tuhan"-nya), amat sulit mengaku salah dan meminta maaf, mungkin selalu benar tetapi tidak popular, tidak menyukai air mata dan emosi, banyak tuntutan pada orang lain.

3) Melankolis (Introvert, pemikir, pesimis).

Pada umumnya mempunyai kepribadian ini adalah mempunyai karakter kecenderungan untuk bersikap rapi, teratur, mempertimbangkan segala sesuatu. Ciri-ciri anak melankolis sekilas dapat dilihat mulai dari buku-bukunya yang terlihat rapi baik tulisan maupun sampul bukunya, berpakaian rapi, secara akademis adalah anak yang cerdas dan pandai. Anak melankolis sangat suka "mengontrol" semuanya sendiri. Ciri lain melankolis adalah bicaranya dingin, suka mengatur, tidak mau kalah. Berhadapan dengan melankolis seperti diinterogasi karena setiap jawaban selalu ia kejar sampai mendalam sebab ia ingin sempurna dan ingin tahu secara lengkap.

Melankolis mempunyai kekuatan sifat: analitis, penuh pikiran, serius dan berorientasi jadwal, artistik dan kreatif, sensitif dan idealis, perfeksionis, sadar perincian/memerinci, tekun, tertib dan teratur (rapi), hemat, dan mencari solusi pemecahan kreatif, kalau sudah mulai dituntaskan, berteman dengan hati-hati, puas di belakang layar, menghindari perhatian, mau mendengar keluhan, setia dan mengabdi, sangat memperhatikan orang lain.

Melankolis mempunyai kelemahan sifat: analitis, mendalam, dan penuh pikiran, serius dan bertujuan, serta berorientasi jadwal, artistik, musikal dan kreatif (filsafat \& puitis), sensitive, mau mengorbankan diri dan idealis, standar tinggi dan perfeksionis, senang perincian/memerinci, tekun, serba tertib dan teratur (rapi), hemat, melihat masalah dan mencari solusi pemecahan kreatif (sering terlalu kreatif), kalau sudah mulai, dituntaskan, berteman dengan hati-hati, puas di belakang layar, menghindari perhatian, mau mendengar keluhan, setia dan mengabdi, sangat memperhatikan orang lain.

Pada umumnya mudah diatur, sangat toleran, diam/kalem, suka mengalah, tidak suka terjadi konflik, karena itu disuruh apa saja ia mau lakukan, sekalipun ia sendiri tidak suka. Jika timbul masalah atau pertengkaran, ia akan mencari solusi damai tanpa timbul pertengkaran. Dengan sabar mau jadi pendengar yang baik, tapi untuk mengambil keputusan ia akan terus menunda-nunda.

\section{Plegmatis Si Cinta Damai}

Kelebihan Plegmatis Si Cinta Damai: sabar, tidak suka konflik, mudah bergaul, santai, tenang dan teguh, sabar, seimbang, pendengar yang baik, tidak banyak bicara, tetapi cenderung bijaksana, simpatik, baik hati (sering menyembunyikan emosi), kuat di bidang administrasi, cenderung ingin segalanya terorganisasi, penengah masalah yang baik, cenderung berusaha menemukan cara termudah, baik di bawah tekanan, menyenangkan dan tidak suka menyinggung perasaan, rasa humor yang tajam, senang melihat dan mengawasi, berbelas kasihan, dan peduli, mudah diajak rukun dan damai.

Kelemahan : tidak suka persaingan, kurang antusias, tidak suka pertikaian, terutama terhadap perubahan/ kegiatan baru, takut dan khawatir, menghindari konflik dan tanggung jawab, keras kepala, sulit kompromi (karena merasa benar), terlalu pemalu dan pendiam, kurang berorientasi pada tujuan, sulit bergerak dan kurang memotivasi diri, lebih suka sebagai penonton daripada terlibat, tidak senang didesak-desak, menunda-nunda/ menggantungkan masalah. 
60 AKSIOMA, Volume 9 Nomor 2, September 2020

\section{LOGICAL REASONING}

Bernalar merupakan aspek fundamental dan salah satu kemampuan yang diharapkan dimiliki dalam mempelajari Matematika. Penalaran merupakan pondasi dalam pembelajaran Matematika. Hal ini memiliki makna bahwa matematika hanya akan manjadi materi yang mengikuti serangkaian prosedur dan meniru contoh-contoh tanpa mengetahui maknanya jika penalaran diabaikan. Materi matematika dipahami melalui penalaran dan penalaran dilatih melalui belajar materi matematika. Jadi penalaran dan matematika tidak dapat dipisahkan (Ackerman \& Thompson, 2017).

Memahami atau merumuskan ide, menemukan relasi antara ide-ide, menggambarkan konklusi tentang ide-ide dan relasi antara ide-ide, merupakan rangkaian aktivitas dinamis yang ada dalam penalaran. Suyitno menyatakan bahwa penalaran dan pemecahan masalah adalah suatu kesatuan. Kusmaryono menjelaskan bahwa penalaran matematika dapat diamati dalam: (1) mengamati pola; (2) membuat generalisasi dan konjektur berkenaan dengan keteraturan yang diamati, (3) menguji konjektur; (4) mengkonstruk dan menilai argumen matematika; dan (5) menvalidasi konklusi logis tentang sejumlah ide dan keterkaitannya (Kusmaryono, Suyitno, Dwijanto, \& Dwidayati, 2018a).

Proses penalaran terdiri atas deduktif dan induktif. Penalaran deduktif merupakan proses berpikir untuk menarik kesimpulan tentang hal khusus yang berpijak pada hal umum. Argumen secara deduktif dapat digunakan untuk memperoleh sebuah kesimpulan yang valid. Penalaran induktif merupakan proses berpikir untuk menarik kesimpulan tentang hal umum yang berpijak pada hal khusus. Argumen secara induktif digunakan untuk memperoleh kesimpulan yang kuat. Pada penalaran induktif, dari kebenaran suatu kasus khusus dapat disimpulkan kebenaran untuk semua kasus.

Beberapa pendapat yang telah di atas, disimpulkan bahwa penalaran matematika adalah proses pengambilan kesimpulan melalui langkah-langkah tertentu berdasarkan fakta dan keterkaitannya saat menyelesaikan masalah matematika.

\section{Kemampuan Penalaran Matematika}

Kemampuan penalaran matematika adalah kemampuan menghubungkan antara ideide atau objek-objek matematika (Zeithamova 2012). Penalaran matematika meliputi: membuat, menyelidiki dan mengevaluasi dugaan matematika. Selain itu mengembangkan argumen-argumen dan bukti-bukti matematika untuk meyakinkan bahwa dugaan yang dikemukakan adalah benar merupakan kerja penalaran. Selanjutnya kemampuan penalaran matematika meliputi: (1) memberikan penjelasan terhadap model, gambar, fakta, sifat, hubungan, atau pola yang ada; (2) memperkirakan jawaban dan proses solusi, dan menggunakan pola dan hubungan untuk menganalisis situasi matematik, menarik analogi dan generalisasi; (3) menyusun dan menguji konjektur, memberikan lawan contoh; dan (4) mengikuti aturan inferensi, menyusun argumen yang valid, memeriksa validitas argumen. Preston menjelaskan kegiatan penalaran matematika meliputi: 1) mengumpulkan fakta; 2) membuat konjektur; 3) menetapkan generelisasi; 4) membangun argumen; 5) menetapkan kesimpulan logis berdasarkan ide atau gagasan dan hubungan-hubungannya (Zeithamova, Schlichting, \& Preston, 2012).

(Paxton, Ungar, \& Greene, 2012) menyebutkan bahwa asesmen penalaran matematika sebaiknya memperhatikan aspek aktivitas metakognitif. Hal ini dapat terlihat pada saat: (1) meminta siswa menformulasikan strategi untuk menyelesaikan masalah serta penjelasannya, (2) meminta siswa memonitor dan mengevaluasi penyelesaian. Peraturan 
Dirjen Dikdasmen No. 506/C/PP/2004. Depdiknas 2004, disebutkan bahwa indikatorindikator penalaran matematika yang harus dicapai oleh siswa, antara lain: (1) kemampuan menyajikan pernyataan matematika secara tertulis, gambar, tabel, dan diagram; (2) kemampuan mengajukan dugaan; (3) kemampuan melakukan manipulasi matematika; (4) kemampuan menyusun bukti dan memberikan alasan terhadap kebenaran solusi; (5) kemampuan memeriksa kesahihan suatu argumen; (6) kemampuan menarik kesimpulan dari pernyataan; (7) menemukan pola atau sifat dari gejala matematis untuk membuat generalisasi.

Beberapa pendapat yang ditelah dikemukakan di atas, disimpulkan bahwa kemampuan penalaran matematika adalah kemampuan menghubungkan, membuat, menyelidiki, menganalisis, dan mengevaluasi ide-ide atau objek-objek matematika untuk menarik suatu kesimpulan yang benar berdasarkan fakta.

2. Indikator Penalaran Matematika dalam Langkah-Langkah Pemecahan Masalah Matematika

Indikator penalaran yang digunakan dalam tulisan ini merujuk pada definisi yang telah dikemukakan di atas.Terdapat empat indikator penalaran yang digunakan yaitu mengumpulkan fakta, mengajukan asumsi, melakukan manipulasi matematika, memeriksa kesahihan asumsi, membangun argumen, dan membuat kesimpulan.

Penyajian antara indikator penalaran dan Langkah pemecahan Masalah menurut Polya dapat dilihat pada tabel berikut.

Tabel 2. Indikator penalaran dalam langkah-langkah pemecahan Polya

\begin{tabular}{|c|c|}
\hline $\begin{array}{l}\text { Pemecahan Masalah } \\
\text { menurut Polya }\end{array}$ & Indikator dan Sub Indikator Penalaran Matematika \\
\hline Langkah ke-1: & Mengumpulkan fakta \\
\hline Memahami masalah & 1. Mampu menyebutkan apa yang diketahui \\
\hline \multirow{2}{*}{ (understanding the problem) } & 2. Mampu menyebutkan apa yang ditanyakan \\
\hline & $\begin{array}{l}\text { 3. Mampu menyebutkan unsur lain yang diperlukan dalam } \\
\text { penyelesaian masalah }\end{array}$ \\
\hline Langkah ke-2: & Mengajukan asumsi. \\
\hline Merencanakan penyelesaian & 1. Mampu menyatakan kembali masalah \\
\hline \multirow[t]{2}{*}{ (devising a plan) } & 2. Mampu menyebutkan strategi yang akan digunakan \\
\hline & $\begin{array}{l}\text { 3. Mampu menyebutkan langkah-langkah penyelesaian yang akan } \\
\text { digunakan }\end{array}$ \\
\hline Langkah ke-3: & Melakukan manipulasi Matematika \\
\hline $\begin{array}{l}\text { Menyelesaikan masalah sesuai } \\
\text { rencana (carrying out the } \\
\text { plan) }\end{array}$ & $\begin{array}{l}\text { Mampu menuliskan langkah-langkah penyelesaian sesuai rencana } \\
\text { yang ditetapkan }\end{array}$ \\
\hline Langkah ke-4: & Memeriksa kesahihan asumsi \\
\hline Melakukan pengecekan & 1. Mampu memeriksa bahwa langkah penyelesaiannya adalah benar \\
\hline \multirow[t]{8}{*}{ kembali (looking back) } & 2. Mampu menunjukkan hasil yang peroleh masuk akal \\
\hline & Membangun argumen \\
\hline & 1. Mampu memberikan alternatif penyelesaian masalah \\
\hline & 2. Mampu menyebutkan gambaran alternatif penyelesaian \\
\hline & $\begin{array}{l}\text { 3. Mampu menyelesaikan masalah sesuai alternatif penyelesaian } \\
\text { masalah }\end{array}$ \\
\hline & Membuat kesimpulan \\
\hline & 1. Mampu menyebutkan kesimpulan yang diperoleh \\
\hline & $\begin{array}{l}\text { 2. Mampu menyebutkan alasan-alasan mengapa kesimpulan adalah } \\
\text { masuk akal/benar }\end{array}$ \\
\hline
\end{tabular}




\section{LINKS BETWEEN HIPPOCRATES PERSONALITY TYPES AND LOGICAL REASONING}

\section{Keterkaitan Penalaran dan Kepribadian}

Penalaran adalah bagian dari proses berpikir yang merupakan aktivitas mental tingkat tinggi. (Richard : 2013) menyatakan "Thinking is process by which a new mental representation is forme $d$ trought the transformation of information by complex interaction of the mental atribute of judging, abtracting, reasonin, and problem solving". Maksud kutipan tersebut adalah berpikir merupakan proses pembentukan representasi mental baru melalui transformasi oleh interaksi yang kompleks antara atribut mental seperti: penilaian, abstraksi, bernalar, membayangkan dan pemecahan masalah. Contoh ketika seseorang membaca buku, informasi diterima melalui berbagai tahapan mulai dari proses sensori sampai dengan ingatan. Informasi ini kemudian ditransformasikan sehingga menghasilkan apa yang disebut intisari sebagai informasi baru, dan hal ini berarti pula sebagai pengetahuan baru bagi orang tersebut.

Meyer menjelaskan bahwa secara normal berpikir meliputi tiga pokok. Pertama, berpikir adalah aktivitas kognitif yang terjadi dalam mental atau pikiran seseorang, tidak tampak tetapi dapat disimpulkan berdasarkan perilaku yang tampak. Misalnya seorang pemain catur memperlihatkan proses berpikirnya melalui langkah-langkah bidak-bidak catur yang dilakukan di atas papan catur. Setiap langkah bidak catur merupakan hasil dari proses berpikir/bernalar yang tidak nampak dari pemain catur tersebut. Kedua, berpikir merupakan suatu proses yang melibatkan beberapa manipulasi pengetahuan di dalam sistem kognitif. Pengetahuan yang tersimpan dalam ingatan digabungkan dengan informasi baru sehingga mengubah pengetahuan seseorang mengenai situasi yang dihadapi. Ketiga, aktivitas berpikir diarahkan dan menghasilkan perbuatan pemecahan masalah atau diarahkan menuju pada pemecahan masalah. Seperti seorang pemain catur, setiap langkah yang dilakukan diarahkan untuk memenangkan permainan, meski tidak semua langkah yang dilakukan berhasil, namun secara umum dalam pikirannya semua langkah diarahkan pada suatu pemecahan ( Richard :2013).

(Richard : 2013) mengemukakan pembelahan kepribadian (dissection of the personality) menjadi tiga bagian, yaitu It, I, dan above-I. Tiap-tiap bagian menunjukkan aspek pribadi dan peran yang berbeda dalam pengambilan keputusan. It menggambarkan aspek naluriah dan tidak bermoral dari kepribadian. It sudah ada sejak lahir, It ingin dipuaskan dan tidak mau penundaan atau ditolak keinginannya dan apabila It tidak mendapatkan kepuasan tersebut, maka akan berdampak pada ketegangan dari diri individu. $I$ adalah aspek pribadi yang juga ada sejak lahir dan menjembatani tuntutan $I t$ maupun dunia luar. $I$ berkembang melalui pengalaman dalam menghadapi sesuatu dalam kehidupan. $I$ juga mengembangkan kemampuan untuk berpikir logis (bernalar). Above-I adalah aspek kepribadian yang berisi aturan-aturan, yang merupakan aspek moral kepribadian yang menilai baik buruk. Contohnya ketika seorang individu haus, sebisa mungkin It mencari apa yang dibutuhkan sebagai pemuas rasa haus, $I$ akan berpikir apakah air yang akan diminum dapat diminum atau tidak dan above-I akan menunjukkan bermacam-macam air yang diperbolehkan diminum dan tidak. Setelah $I$ selesai melakukan proses berpikir sesuai petunjuk above-I maka $I$ akan mengirim informasi hasil berpikir/bernalar kepada It untuk mengambil keputusan apakah akan minum atau tidak.

Berdasarkan pendapat di atas dapat dikatakan ada keterkaitan antara tindakan dengan proses berpikir pada seseorang. Tindakan seseorang muncul sebagai hasil aktivitas 
kognitif (penalaran). Hubungan antara $I t, I$ dan above-I dalam diri seseorang merupakan kunci keseimbangan dalam menentukan kepribadian seorang individu. It (memindahkan bidak catur) merupakan penuntut kepuasan, I (aktivitas kognitif). merupakan sebuah penalaran dan pemahaman diri individu terhadap tindakan yang akan diambil oleh it dan above-I (aturan dalam bermain catur) merupakan komponen yang menyempurnakan dan mengatur keseimbangan antara It dan I. Jadi, penalaran diindikasikan sebagai aspek penting dari kepribadian.

\section{Keterkaitan Penalaran dengan Tipe Kepribadian berdasarkan Hippocrates}

Setiap individu mempunyai kepribadian yang berbeda-beda dan akan nampak ketika merespon keadaan/lingkungan di sekitarnya dengan cara yang berbeda pula sesuai dengan tipe kepribadian dan tingkat pengetahuan yang dimiliki. Respon ini dapat berupa bahasa, perilaku, perasaan dan pemikiran seseorang (S. Leung, \& M. Bond.:2001). Bahasa merupakan alat komunikasi verbal untuk menyampaikan jalan pikiran tersebut kepada orang lain. Dengan menguasai bahasa maka seseorang akan mengetahui pengetahuan. Tanpa bahasa maka seseorang tidak akan dapat berpikir secara rumit dan abstrak, termasuk dalam kegiatan pembelajaran matematika. Dengan kata lain, tanpa mempunyai kemampuan berbahasa maka kegiatan berpikir secara sistematis dan teratur tidak mungkin dapat dilakukan. Hal ini sesuai dengan pendapat (Kusmaryono, Suyitno, Dwijanto, \& Dwidayati, 2018b) mengutarakan betapa dekatnya pengaruh berpikir terhadap berbahasa dalam proses pembelajaran seorang anak. Kedekatan itu digambarkan bahwa bahasa adalah cermin dari pikiran seorang anak.

(Coady, 2001) berpendapat bahwa bahasa dan pemikiran (penalaran) pada awalnya berkembang secara independent satu sama lain dan kemudian bergabung. Coady menjelaskan bahwa semua fungsi mental (berpikir/bernalar) memiliki asal usul eksternal atau sosial. Bahasa digunakan untuk berkomunikasi dengan orang lain sebelum seseorang dapat berfokus pada pemikiran-pemikiran (penalaran) mereka. Berbeda dengan pendapat (Gardner, 2015) bahwa bahasa tampil ketika sudah mencapai tahap perkembangan (penalaran) yang sudah maju. Pengalaman berbahasa seseorang bergantung pada tahap perkembangan kognitif saat itu. (Jeannotte \& Kieran, 2017) menjelaskan bahwa hubungan antara pikiran dan bahasa bukanlah merupakan suatu benda, melainkan merupakan satu proses, satu gerak yang terus-menerus dari pikiran ke kata (bahasa) dan dari kata (bahasa) ke pikiran.

Menurut (Bradford, Live Science, \& Science, 2017) struktur pikiran dibentuk oleh perilaku dan bukan oleh struktur bahasa. Struktur pikiran mendahului kemampuankemampuan yang dipakai untuk berbahasa. Lebih luas dijelaskan bahwa jenis penalaran yang dimiliki masing-masing orang paling berpengaruh pada perilaku, perasaan, dan pemikirannya. Kesalahan berpikir akan mengacu pada kecenderungan seseorang dalam melihat dunia dari sudut pandangnya sendiri. Pengaruh penalaran terhadap perilaku, perasaan, dan pemikiran anak diilustrasikan lewat studi klasik egosentris, realitas moral, dan konservasi siswa. Piaget dan Inhelder melakukan percobaan tiga gunung "papier mache". Dari percobaan ini didapati siswa dibawah umur 7 tahun mengalami kesulitan dengan tugas ini dan cenderung memilih gambar dari sudut pandang mereka sendiri. Pada pemikiran yang lebih abstrak, Piaget melakukan observasi tentang konsep moralitas kepada beberapa anak untuk melihat benar dan salah dari satu sudut pandang. Hasil wawancara klinis menunjukkan bahwa anak-anak tidak bisa mempertimbangkan alasan-alasan orang lain karena anak-anak belum mampu memahami situasi dari sudut pandang orang lain. Lebih tajam lagi melalui percobaan konservasi terhadap zat cair, Piaget menemukan 
ketidakmampuan anak membedakan banyaknya cairan yang sama dalam bejana yang berbeda. Dari beberapa percobaannya, Piaget menunjukkan bahwa kemampuan penalaran seseorang akan berpengaruh terhadap perasaan, perilaku dan pemikirannya.

(Gardner, 2015) bahwa sifat-sifat umum aktivitas manusia antara lain: perhatian, pengamatan, tanggapan, fantasi, ingatan, berpikir, perasaan, dan motif. Berpangkal dari sifat-sifat umum ini, terbentuk kepribadian manusia yang bemacam-macam, mungkin sama banyaknya dengan banyaknya orang. Segolongan ahli menggolongkan manusia ke dalam tipe-tipe tertentu untuk memenuhi tujuan psikologi kepribadian, yaitu mengenal manusia menurut apa adanya, menurut sifat-sifatnya yang khas. Hippocrates menggolongkan tipe kepribadian manusia berdasarkan cairan biologis yang dominan dalam tubuh manusia yaitu sanguinis, koleris, melankolis, dan plegmatis.

Perasaan umumnya bersangkutan dengan fungsi mengenal; artinya perasaan dapat timbul karena mengamati, menanggapi, menghayal, mengingat, atau memikirkan sesuatu. Lebih lanjut Suryabrata menjelaskan bahwa bersifat subyektif yang dipengaruhi oleh keadaan diri seseorang. Perasaan juga melatarbelakangi dan mendasari aktivitas-aktivitas manusia. Karena itu dalam pendidikan seharusnya diusahakan adanya perasaan yang membantu pelaksanaan usaha yang sedang dilakukan. Paparan di atas, dapat disimpulkan bahwa kemampuan penalaran seseorang akan berpengaruh terhadap bahasa, perilaku, perasaan, dan pemikiran seseorang. Aspek-aspek yang dipengaruhi kemampuan penalaran adalah faktor-faktor yang membentuk kepribadian.

Setiap individu mempunyai kepribadian yang berbeda-beda dan akan nampak ketika merespon keadaan/lingkungan di sekitarnya dengan cara yang berbeda pula sesuai dengan tipe kepribadian dan tingkat pengetahuan yang dimiliki. Respon ini dapat berupa bahasa, perilaku, perasaan dan pemikiran seseorang (Gardner, 2015). Bahasa merupakan alat komunikasi verbal untuk menyampaikan jalan pikiran tersebut kepada orang lain. Dengan menguasai bahasa maka seseorang akan mengetahui pengetahuan. Tanpa bahasa maka seseorang tidak akan dapat berpikir secara rumit dan abstrak, termasuk dalam kegiatan pembelajaran matematika. Dengan kata lain, tanpa mempunyai kemampuan berbahasa maka kegiatan berpikir secara sistematis dan teratur tidak mungkin dapat dilakukan. Hal ini sesuai dengan pendapat (Jeannotte \& Kieran, 2017) mengutarakan betapa dekatnya pengaruh berpikir terhadap berbahasa dalam proses pembelajaran seorang anak. Kedekatan itu digambarkan bahwa bahasa adalah cermin dari pikiran seorang anak.

(Jeannotte \& Kieran, 2017) bahwa bahasa dan pemikiran (penalran) pada awalnya berkembang secara independent satu sama lain dan kemudian bergabung. Lebih lanjut (Jeannotte \& Kieran, 2017) menjelaskan bahwa semua fungsi mental (berpikir/bernalar) memiliki asal usul eksternal atau sosial. Bahasa digunakan untuk berkomunikasi dengan orang lain sebelum seseorang dapat berfokus pada pemikiran-pemikiran (penalaran) mereka. Berbeda dengan pendapat (Jeannotte \& Kieran, 2017) bahwa bahasa tampil ketika sudah mencapai tahap perkembangan (penalaran) yang sudah maju. Pengalaman berbahasa seseorang bergantung pada tahap perkembangan kognitif saat itu. Selanjutnya (Jeannotte \& Kieran, 2017) menjelaskan bahwa hubungan antara pikiran dan bahasa bukanlah merupakan suatu benda, melainkan merupakan satu proses, satu gerak yang terus-menerus dari pikiran ke kata (bahasa) dan dari kata (bahasa) ke pikiran.

(Jeannotte \& Kieran, 2017) struktur pikiran dibentuk oleh perilaku dan bukan oleh struktur bahasa. Struktur pikiran mendahului kemampuan-kemampuan yang dipakai untuk berbahasa. Lebih luas Piaget menjelaskan bahwa jenis penalaran yang dimiliki masingmasing orang paling berpengaruh pada perilaku, perasaan, dan pemikirannya. Kesalahan berpikir akan mengacu pada kecenderungan seseorang dalam melihat dunia dari sudut 
pandangnya sendiri. Pengaruh penalaran terhadap perilaku, perasaan, dan pemikiran anak diilustrasikan lewat studi klasik egosentris, realitas moral, dan konservasi siswa. Piaget dan Inhelder melakukan percobaan tiga gunung "papier mache". Dari percobaan ini didapati siswa dibawah umur 7 tahun mengalami kesulitan dengan tugas ini dan cenderung memilih gambar dari sudut pandang mereka sendiri. Pada pemikiran yang lebih abstrak Piaget melakukan observasi tentang konsep moralitas kepada beberapa anak untuk melihat benar dan salah dari satu sudut pandang. Hasil wawancara klinis menunjukkan bahwa anak-anak tidak bisa mempertimbangkan alasan-alasan orang lain karena anak-anak belum mampu memahami situasi dari sudut pandang orang lain. Lebih tajam lagi melalui percobaan konservasi terhadap zat cair Piaget menemukan ketidakmampuan anak membedakan banyaknya cairan yang sama dalam bejana yang berbeda. Dari beberapa percobaannya, Piaget menunjukkan bahwa kemampuan penalaran seseorang akan berpengaruh terhadap perasaan, perilaku dan pemikirannya.

Menurut Suryabrata bahwa sifat-sifat umum aktivitas manusia antara lain: perhatian, pengamatan, tanggapan, fantasi, ingatan, berpikir, perasaan, dan motif. Berpangkal dari sifat-sifat umum ini, terbentuk kepribadian manusia yang bemacammacam, mungkin sama banyaknya dengan banyaknya orang. Segolongan ahli menggolongkan manusia ke dalam tipe-tipe tertentu untuk memenuhi tujuan psikologi kepribadian, yaitu mengenal manusia menurut apa adanya, menurut sifat-sifatnya yang khas. Hippocrates menggolongkan tipe kepribadian manusia berdasarkan cairan biologis yang dominan dalam tubuh manusia yaitu sanguinis, koleris, melankolis, dan plegmatis.

Perasaan umumnya bersangkutan dengan fungsi mengenal; artinya perasaan dapat timbul karena mengamati, menanggapi, menghayal, mengingat, atau memikirkan sesuatu. Lebih lanjut Suryabrata menjelaskan bahwa bersifat subyektif yang dipengaruhi oleh keadaan diri seseorang. Perasaan juga melatarbelakangi dan mendasari aktivitas-aktivitas manusia. Karena itu dalam pendidikan seharusnya diusahakan adanya perasaan yang membantu pelaksanaan usaha yang sedang dilakukan.

Paparan di atas, dapat disimpulkan bahwa kemampuan penalaran seseorang akan berpengaruh terhadap bahasa, perilaku, perasaan, dan pemikiran seseorang. Aspek-aspek yang dipengaruhi kemampuan penalaran adalah faktor-faktor yang membentuk kepribadian.

\section{METODE}

Instrumen utama penelitian ini adalah peneliti sendiri yang dipandu dengan beberapa instrumen yang berupa instrumen tes kepribadian, instrumen tes tertulis, dan pedoman wawancara. Peneliti sebagai instrumen utama merupakan perencana, pelaksana, pengumpul data, penganalisis data, penafsir data, dan akhirnya menjadi pelapor hasil penelitiannya.

Penelitian ini dilaksanakan di MAN Baraka Enrekang. Jumlah siswa yang banyak memungkinkan memperoleh subjek untuk masing-masing tipe kepribadian. Prosedur pemilihan subjek dalam penelitian ini dapat dilihat pada Gambar 1 berikut: 
66 AKSIOMA, Volume 9 Nomor 2, September 2020

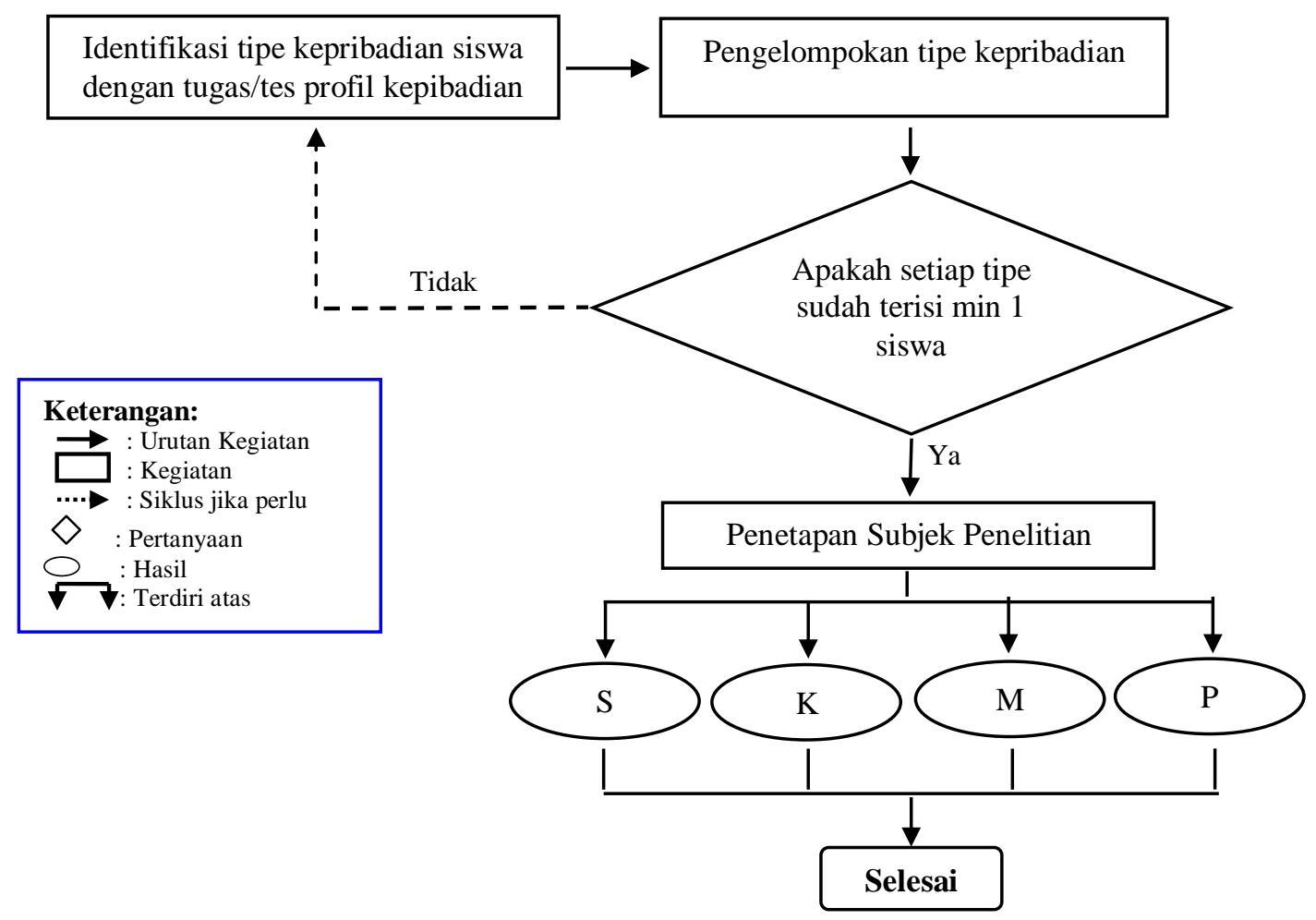

Gambar 1. Alur Pemilihan Subjek Penelitian

\section{HASIL}

Hasil identifikasi tipe kepribadian dapat dilihat pada Tabel 3.

Tabel 3. Hasil Identifikasi Tipe Kepribadian

\begin{tabular}{llcc}
\hline No & Tipe kepribadian & Jumlah & Persentase (\%) \\
\hline \hline 1 & Sanguinis (S) & 2 & 6,67 \\
\hline 2 & Koleris (K) & 1 & 3,33 \\
\hline 3 & Melankolis (M) & 11 & 13,33 \\
\hline 4 & Plegmatis (P) & 1 & 36,67 \\
\hline 8 & Melankolis (M) dan Plegmatis (P) & 11 & 6,67 \\
\hline 9 & Tidak mendominasi tipe kepribadian & 30 & 36,67 \\
\hline & Jumlah & & 100 \\
\hline
\end{tabular}

Subjek untuk masing-masing tipe kepribadian dipilih dari sifat yang paling dominan pada setiap jenis kepribadian. Ilustrasi subjek yang terpilih pada masing-masing tipe dapat dilihat pada gambar berikut ini: 

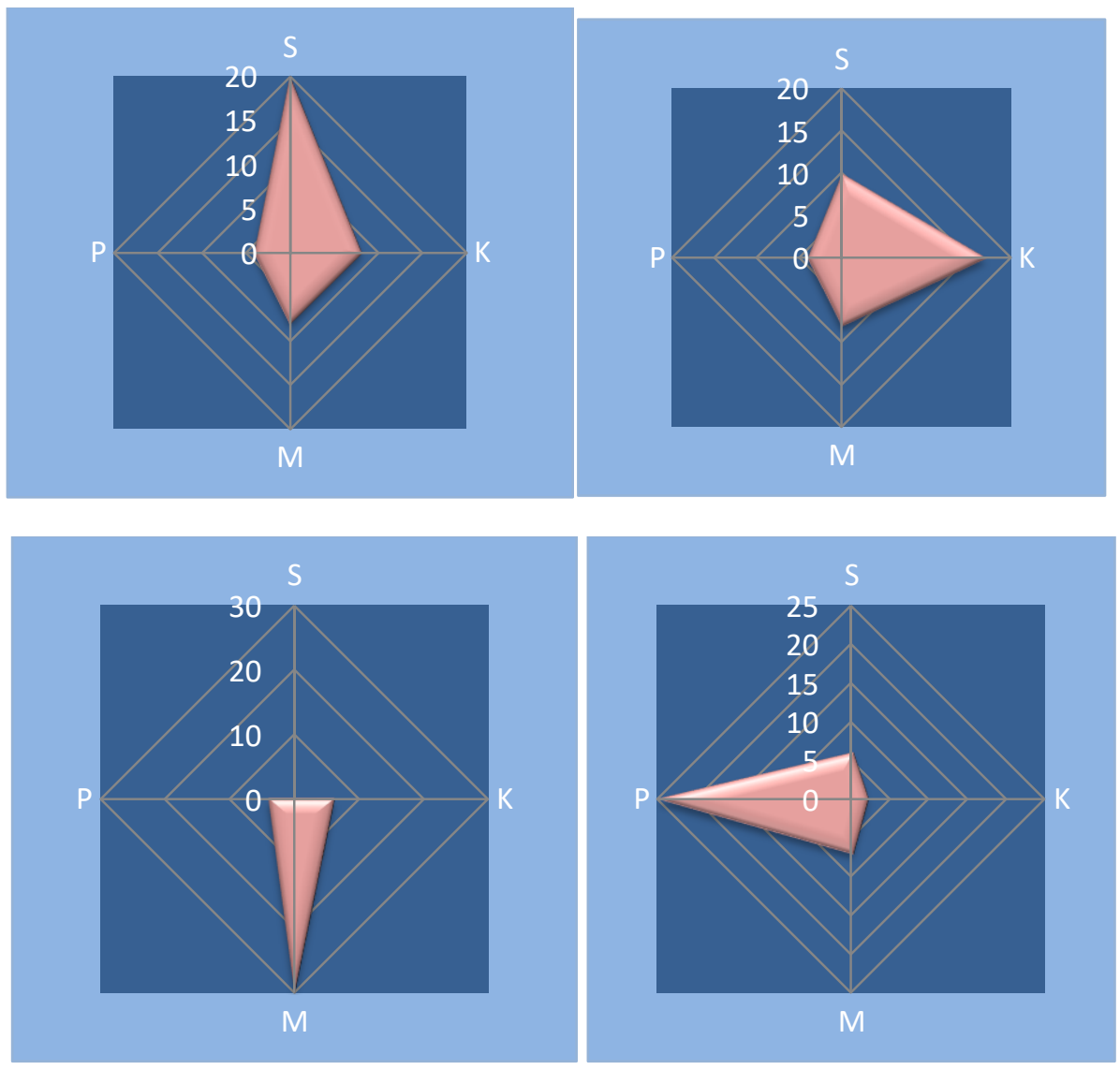

Gambar 2. Ilustrasi Tipe Kepribadian Subjek

Tabel 4. Gambaran Penalaran Sanguinis

\begin{tabular}{lll}
\hline No. & \multicolumn{1}{c}{ Indikator } & \multicolumn{1}{c}{ Gambaran Penalaran } \\
\hline Fengumpulkan & Menyebutkan unsur-unsur yang diketahui dalam tes tertulis soal secara \\
& lengkap & \\
& Menyebutkan unsur-unsur yang ditanyakan sesuai dengan apa yang ada \\
& pada tes. \\
& Menyebutkan unsur-unsur lain yang diperlukan dalam penyelesaian \\
& masalah secara jelas \\
& Menyatakan informasi dengan menggunakan simbol-simbol Matematika \\
& Menyatakan kembali masalah sesuai dalam tes tertulis soal secara lengkap \\
& Mengajukan jelas & \\
asumsi & Mempunyai cara atau strategi penyelesaian masalah dan memberi \\
& gambaran penyelesaiannya secara lengkap. \\
& Menyebutkan langkah-langkah penyelesaian masalah secara singkat. \\
& Cara atau strategi penyelesaiannya menggunakan rumus. \\
& Menyatakan informasi menggunakan simbol-simbol Matematika \\
& Menuliskan unsur yang diketahui dan unsur lain yang diperlukan dalam \\
& pemecahan masalah sesuai dengan apa yang disebutkan pada langkah \\
& Memahami masalah tetapi tidak menuliskan unsur yang ditanyakan \\
Manipulasi & Matematika & Merbeda antara lisan dan tertulis) \\
& Menuliskan langkah-langkah penyelesaian masalah sesuai yang \\
& direncanakan tetapi tidak serinci pada bagian pengajuan asumsi \\
& Menunjukkan langkah-langkah penyelesaian masalah secara benar dengan \\
& pengecekan langkah demi langkah secara jelas, detail dan terurut
\end{tabular}


68 AKSIOMA, Volume 9 Nomor 2, September 2020

4. Memeriksa

Memeriksa kebenaran hasil yang diperoleh dan memberikan alasannya

Kesahihan asumsi Mengecek kesahihan atau kebenaran hasil yang diperoleh langkah demi langkah

Menunjukkan hasil yang diperoleh berdasarkan hasil penyelesaian dengan pengecekan mundur dan memberikan alasannya berdasarkan hasil penyelesaiannya

Menunjukkan hasil yang diperoleh berdasarkan hasil penyelesaian dan memberikan alasannya berdasarkan hasil penyelesaian tetapi kadang tidak konsisten

5. Membangun Mempunyai penyelesaian alternatif untuk memperoleh hasil yang sama Argumen (ada unsur kreatif) Mampu menyatakan gambaran penyelesaian dengan cara yang berbeda secara jelas

Menuliskan langkah-langkah penyelesaian dengan cara yang berbeda secara singkat

Ada kecenderungan memberikan informasi secara singkat dan jelas

6. Membuat Mampu membuat kesimpulan dan memberikan alasannya berdasarkan hasil Kesimpulan penyelesaian tes tertulis Mempunyai penyelesaian dengan cara yang berbeda dalam menyelesaikan masalah

Meyakini kesimpulan berdasarkan hasil penyelesaiannya melalui pengecekan mundur

Tabel 5. Gambaran Penalaran Koleris dalam Memecahkan Masalah

\begin{tabular}{|c|c|c|}
\hline No & Indikator & Gambaran Penalaran \\
\hline 1. & $\begin{array}{l}\text { Mengumpulkan } \\
\text { Fakta }\end{array}$ & $\begin{array}{l}\text { Menyebutkan unsur-unsur yang diketahui sesuai dalam tes tertulis, tidak } \\
\text { lengkap } \\
\text { Menyebutkan unsur-unsur ditanyakan sesuai dengan apa yang } \\
\text { ditanyakan dalam tes tertulis } \\
\text { Tidak menyebutkan unsur-unsur lain yang diperlukan dalam pemecahan } \\
\text { masalah } \\
\text { Ada kecenderungan menyatakan informasi berdasarkan konteks tes } \\
\text { tertulis pada soal }\end{array}$ \\
\hline 2. & $\begin{array}{l}\text { Mengajukan } \\
\text { Asumsi }\end{array}$ & $\begin{array}{l}\text { Menyatakan kembali masalah sesuai dengan tes tertulis secara lengkap } \\
\text { dan jelas } \\
\text { Mempunyai cara atau strategi penyelesaian masalah tetapi tidak mampu } \\
\text { memberi gambaran penyelesaiannya } \\
\text { Cara atau strategi penyelesaiannya menggunakan cara yang berbeda dan } \\
\text { menyebutkan langkah-langkah penyelesaiannya secara tidak terurut pada } \\
\text { M1 } \\
\text { Cara atau strategi penyelesaiannya menggunakan rumus dan } \\
\text { menyebutkan langkah-langkah penyelesaiannya secara tidaklengkap. } \\
\text { Ada kecenderungan menyatakan informasi secara garis besar dan singkat }\end{array}$ \\
\hline 3. & $\begin{array}{l}\text { Melakukan } \\
\text { Manipulasi } \\
\text { Matematika }\end{array}$ & $\begin{array}{l}\text { Tidak menuliskan unsur yang diketahui, unsur yang ditanyakan, dan } \\
\text { unsur lain dalam penyelesaian sesuai dengan apa yang disebutkan pada } \\
\text { langkah memahami masalah } \\
\text { Menuliskan langkah-langkah penyelesaian masalah sesuai yang } \\
\text { direncanakan secara singkat dan tidak terurut.(tergesa gesa) } \\
\text { Menunjukkan langkah-langkah penyelesaian masalah dengan } \\
\text { pengecekan langkah demi langkah secara detail, jelas dan tidak terurut }\end{array}$ \\
\hline 4. & $\begin{array}{l}\text { Memeriksa } \\
\text { Kesahihan Asumsi }\end{array}$ & $\begin{array}{l}\text { Memeriksa kesahihan atau kebenaran hasil yang diperoleh dan } \\
\text { memberikan alasannya } \\
\text { Mengecek kesahihan atau kebenaran hasil yang diperoleh langkah demi } \\
\text { langkah } \\
\text { Menunjukkan hasil yang diperoleh berdasarkan hasil penyelesaian }\end{array}$ \\
\hline
\end{tabular}


5. Membangun Argumen

6. Membuat Kesimpulan dengan pengecekan mundur

Memberikan alasan berdasarkan hasil penyelesaian dan pertanyaan yang diajukan

Mempunyai penyelesaian dengan cara yang berbeda untuk memperoleh hasil sama.

Menuliskan langkah-langkah penyelesaian dengan cara yang berbeda secara singkat

Ada kecenderungan memberikan informasi secara singkat dan jelas

Membuat kesimpulan berdasarkan pertanyaan yang diajukan dalam tes tertulis soal.

Mempunyai penyelesaian dengan cara yang berbeda

Meyakinkan kesimpulan berdasarkan hasil penyelesaian tes tertulis

Tabel 6. Gambaran Penalaran Melancolic dalam Memecahkan Masalah

\begin{tabular}{|c|c|c|}
\hline No & Indikator & Gambaran Penalaran \\
\hline 1. & $\begin{array}{l}\text { Mengumpulkan } \\
\text { Fakta }\end{array}$ & $\begin{array}{l}\text { Menyebutkan unsur-unsur yang diketahui dalam soal secara lengkap dan } \\
\text { jelas } \\
\text { Menyebutkan unsur-unsur ditanyakan sesuai dengan apa yang } \\
\text { ditanyakan dalam soal. } \\
\text { Menyebutkan unsur-unsur lain yang diperlukan dalam pemecahan } \\
\text { masalah } \\
\text { Ada kecenderungan menyatakan informasi berdasarkan konteks tes } \\
\text { tertulis yang diajukan. }\end{array}$ \\
\hline 2. & $\begin{array}{l}\text { Mengajukan } \\
\text { asumsi }\end{array}$ & $\begin{array}{l}\text { Menyatakan kembali masalah sesuai tes tertulis secara lengkap dan jelas } \\
\text { Mempunyai cara atau strategi penyelesaian masalah dan memberi } \\
\text { gambaran penyelesaiannya secara rinci dan jelas (sempurna) } \\
\text { Menyebutkan langkah-langkah penyelesaian masalah secara terurut dan } \\
\text { rinci (merinci) } \\
\text { Memiliki cara lain penyelesaian yang digunakan dengan cara yang } \\
\text { berbeda (kreatif) } \\
\text { Ada kecenderungan menyatakan informasi dengan cara menghitung } \\
\text { unsur-unsur pada soal (merinci) }\end{array}$ \\
\hline 3. & $\begin{array}{l}\text { Melakukan } \\
\text { Manipulasi } \\
\text { Matematika }\end{array}$ & $\begin{array}{l}\text { Menuliskan unsur yang diketahui dan unsur yang ditanyakan sesuai } \\
\text { dengan apa yang disebutkan pada langkah memahami masalah } \\
\text { (konsisten) } \\
\text { Menuliskan secara jelas dan terurut langkah-langkah penyelesaian } \\
\text { masalah sesuai yang direncanakan (teratur dan konsisten) } \\
\text { Menunjukkan langkah-langkah penyelesaian masalah secara benar } \\
\text { dengan pengecekan langkah demi langkah secara jelas, detail, terurut. }\end{array}$ \\
\hline 4. & $\begin{array}{l}\text { Memeriksa } \\
\text { Kesahihan Asumsi }\end{array}$ & $\begin{array}{l}\text { Memeriksa kesahihan atau kebenaran hasil yang diperoleh dan } \\
\text { memberikan alasannya } \\
\text { Mengecek kesahihan atau kebenaran hasil yang diperoleh langkah demi } \\
\text { langkah } \\
\text { Memberikan alasannya berdasarkan pertanyaan yang diajukan dalam } \\
\text { soal dan hasil penyelesaian.(analitis) }\end{array}$ \\
\hline
\end{tabular}

5. Membangun Mempunyai penyelesaian dengan cara yang berbeda untuk memperoleh Argumen

hasil yang sama dalam menyelesaikan masalah (keatif)

Menyatakan gambaran penyelesaian dengan cara yang berbeda (kreatif)

Menuliskan langkah-langkah penyelesaian dengan cara yang berbeda

Memanfaatkan pengalaman untuk meyelesaian masalah yang sama

6. Membuat Membuat kesimpulan dan memberikan alasannys berdasarkan hasil Kesimpulan penyelesaian tes tertulis (analitis)

Mempunyai penyelesaian dengan cara yang berbeda dalam penyelesaian yang masalah (kreatif) 
70 AKSIOMA, Volume 9 Nomor 2, September 2020

Meyakinkan kesimpulan berdasarkan hasil penyelesaian tes tertulis (konsisten)

Tabel 7. Gambaran Penalaran Plegmatis

\begin{tabular}{|c|c|c|}
\hline No & Indikator & Gambaran Penalaran \\
\hline 1. & $\begin{array}{l}\text { Mengumpulkan } \\
\text { Fakta }\end{array}$ & $\begin{array}{l}\text { Menyebutkan unsur-unsur yang diketahui dalam soal secara lengkap dan } \\
\text { jelas (detail) } \\
\text { Menyebutkan unsur-unsur ditanyakan sesuai dengan apa yang } \\
\text { ditanyakan dalam tes tertulis soal Matematika } \\
\text { Menyebutkan unsur-unsur lain yang diperlukan dalam pemecahan } \\
\text { masalah secara jelas(analitis) } \\
\text { Ada kecenderungan menyatakan informasi menggunakan simbol-simbol } \\
\text { Matematika }\end{array}$ \\
\hline 2. & $\begin{array}{l}\text { Mengajukan } \\
\text { asumsi }\end{array}$ & $\begin{array}{l}\text { Menyatakan kembali masalah sesuai dengan tes tertulis soal Matematika } \\
\text { secara lengkap dan jelas (konsisten) } \\
\text { Mempunyai cara atau strategi penyelesaian masalah dan memberi } \\
\text { gambaran penyelesaiannya secara jelas (perencanaan matang)/ } \\
\text { Menyebutkan secara berurut langkah-langkah penyelesaian masalah } \\
\text { (teratur) } \\
\text { Cara atau strategi penyelesaiannya menggunakan rumus baris dan deret } \\
\text { aritmatika } \\
\text { Ada kecenderungan menyampaikan informasi secara detail }\end{array}$ \\
\hline 3. & $\begin{array}{l}\text { Melakukan } \\
\text { Manipulasi } \\
\text { Matematika }\end{array}$ & $\begin{array}{l}\text { Menuliskan unsur yang diketahui, unsur yang ditanyakan dan unsur yang } \\
\text { diperlukan dalam penyelesaian sesuai dengan yang disebutkan pada } \\
\text { langkah memahami masalah (konsisten) } \\
\text { Menuliskan langkah-langkah penyelesaian masalah sesuai yang } \\
\text { direncanakan secara jelas, terperinci dan terurut(ditulis dengan tenang } \\
\text { dan sabar) } \\
\text { Menunjukkan langkah-langkah penyelesaian masalah dengan } \\
\text { pengecekan langkah demi langkah secara detail, jelas, terperinci dan } \\
\text { terurut }\end{array}$ \\
\hline 4. & $\begin{array}{l}\text { Memeriksa } \\
\text { Kesahihan asumsi }\end{array}$ & $\begin{array}{l}\text { Memeriksa kesahihan atau kebenaran hasil yang diperoleh dan } \\
\text { memberikan alasannya } \\
\text { Mengecek kesahihan atau kebenaran hasil yang diperoleh langkah demi } \\
\text { langkah dengan jelas } \\
\text { Menunjukkan hasil yang diperoleh dan memberikan alasannya } \\
\text { berdasarkan hasil penyelesaian }\end{array}$ \\
\hline 5. & $\begin{array}{l}\text { Membangun } \\
\text { Argumen }\end{array}$ & $\begin{array}{l}\text { Mempunyai penyelesaian yang berbeda untuk memperoleh hasil yang } \\
\text { sama dalam menyelesaikan masalah (kreatif) } \\
\text { Menyatakan gambaran penyelesaian dengan cara yang berbeda secara } \\
\text { detail } \\
\text { Menuliskan langkah-langkah dari penyelesaian dengan cara yang } \\
\text { berbeda secara terperinci. (rinci dan detail) } \\
\text { Ada kecenderungan memberikan informasi tertulis secara detail dan } \\
\text { terperinci } \\
\text { Ada kecenderungan memanfaatkan pengalaman untuk menyelesaian } \\
\text { masalah yang sama (analitis) } \\
\text { Ada kecenderungan menyatakan informasi dalam bentuk gambar atau } \\
\text { diagram }\end{array}$ \\
\hline 6. & $\begin{array}{l}\text { Membuat } \\
\text { Kesimpulan }\end{array}$ & $\begin{array}{l}\text { Membuat kesimpulan dan memberikan alasannya berdasarkan hasil } \\
\text { penyelesaian tes tertulis (terfokus) } \\
\text { Mempunyai penyelesaian dengan cara yang berbeda dalam } \\
\text { menyelesaikan masalah } \\
\text { Meyakinkan kesimpulan berdasarkan hasil penyelesaian tes tertulis. }\end{array}$ \\
\hline
\end{tabular}




\section{PEMBAHASAN}

Penjaringan subjek dilakukan melalui tes kepribadian. Hal ini dilakukan dengan menggunakan tes Personality Plus (Littauer's book). Hasil diperoleh $36.67 \%$ adalah plegmatis, melankolis sebanyak $13.33 \%$, sanguinis sebanyak $6,67 \%$ dan koleris sebanyak $3.33 \%$. Setelah diperoleh komposisi masing-masing tipe kepribadian, selanjutnya dipilih satu orang subjek mewakili masing-masing tipe untuk mengungkap gambaran penarannya.

Sanguinis, terhadap enam indikator penalaran logis, hal yang paling menonjol adalah dapat memberikan penjelasan secara lisan dengan sempurna pada indikator mengumpulkan fakta. Selanjutnya pada langkah mengajukan asumsi, penjelasan langkah demi langkah dapat diuraikan dengan jelas. Selain itu sifat kreatifnya juga muncul. Hal ini dapat dilihat pada indikator mengajukan asumsi dia dapat memikirkan lebih dari satu cara penyelesaian. Pada saat melakukan manipulasi matematika, pada pekerjaan tertulisnya sering terjadi coretan yang menandakan kesalahan. Hal ini terjadi mungkin karena turunan dari sifatnya yang tergesa-gesa dalam bekerja. Selain itu penjelasan secara lisan terkadang lebih bagus dari pada penjelasan secara tertulis. Langkah-langkah penyelesaian yang diuraikan secara rinci pada saat pengajuan asumsi, berbeda/tidak dilakukan secara sempurna pada indikator melakukan manipulasi matematika. Hal ini terjadi sebagai turunan dari sifatnya yang sering pelupa.

Koleris, terhadap enam indikator penalaran logis, ada beberapa hal yang menonjol. Pada indikator mengumpulkan fakta, unsur-unsur masalah dapat disebutkan secara lengkap. Pada langkah pengajuan asumsi, penjelasan langkah-langkah penyelesaian diuraikan secara sederhana dan singkat, tetapi benar. Pada saat melakukan manipulasi matematika, langkah penyelesaian dilakukan secara singkat dan cepat. Hal ini terjadi sebagai turunan dari sifatnya, mencari pemecahan praktis dan bergerak cepat, tidak suka yang terlalu rinci.

Sifat yang selalu ingin tampil sempurna dan selalu merupakan ciri khusus dari subjek sunguinis. Hal ini dapat dilihat pada pengumpulan fakta dilakukan secara terurut, sesuai dengan apa yang tercantum pada soal. Pada langkah pengajuan asumsi, dapat menyatakan masalah secara lengkap, langkah-langkah penyelesaian diuraikan secara rinci dan jelas. Memiliki langkah penyelesaian yang lain dan mampu dijelaskan dengan sempurna. Hal muncul sebagai sifatnya selalu ingin melakukan sesuatu dengan sempurna. Pada saat melakukan manipulasi matematika, langkah penyelesaiannya dituliskan dengan teratur, sesuai dengan langkah-langkah yang telah diuraikan pada pengajuan asumsi. Ada konsisten antara pengajuan asumsi dan manipulasi matematika. Langkah-langkah dalam melakukan manipulasi matematika dapat dijelaskan dengan rinci dan disertai argummen tepat.

Sifat tenang dan sabar merupakan ciri khas dari subjek plegmatis. Mengumpulkan fakta secara detail dan terpaku pada informasi pada soal. Mampu mencari kaitan masalah dengan informasi yang dibutuhkan. Langkah-langkah penyelesaian diuraikan dengan pelan dan terinci. Kecenderungan ada konsistensi antara perencanaan dengan pelaksanaan. Kadang ragu terhadap kesimpulan yang telah dibuatnya, tetapi mampu memberikan alasan atau penjelasan terhadap apa langkah-langkah penyelesaian yang telah dibuatnya.

\section{KESIMPULAN}

Kajian tentang kepribadian merupakan kajian yang sangat penting, populer, serta memiliki aplikasi yang luas dalam bidang pendidikan. Selama ini kajian tentang personality di beberapa negara lebih banyak dalam bidang psychology. Hubungan antara personality dengan proses berpikir membuka fakta baru suatu area penelitian. Pada penelitian ini, 
melalui kajian yang sangat kredibel mengamati hubungan antara penalaran dengam Hippocrates personality. Tipe kepribadian yang berbeda tidak memberikan perbedaan penalaran yang tegas. Namun demikian, beberapa sifat-sifat kepribadian seperti sabar, kreatif, ragu-ragu, teliti, analitis, terinci dan teratur, kempuan bergumen, optimis tetap menjadi ciri untuk masing-masing kepribadian muncul dalam indikator-indikator penalarannya. Hasil penelitian ini memberikan peluang yang lebih besar untuk melakukan kajian lebih luas dan mendalam tentang kepribadian dan penalaran.

\section{DAFTAR PUSTAKA}

Ackerman, R., \& Thompson, V. A. (2017). Meta-Reasoning: Monitoring and Control of Thinking and Reasoning. Trends in Cognitive Sciences. https://doi.org/10.1016/j.tics.2017.05.004

Abraham, Amit. 2007. Personality Development Through Positive Thinking, Jogjakarta: Diglossia Media.

Atta, M., Ather, M., \& Bano,M. (2013). Emotional Intelligence and Personality Traits among University Teachers: Relationship and Gender Differences. International Journal of Business and Social Science . 4 (17), 253-259 Retrieved from http://www.researchpub.org/journal/ijssh/ijssh.html

Bradford, A., Live Science, \& Science, L. (2017). Deductive Reasoning vs. Inductive Reasoning.

Coady, D. (2001). Reasoning, Meaning, and Mind. Australasian Journal of Philosophy. https://doi.org/10.1080/713659251

Emanuel, R. C.(2013). Do Certain Personality Types Have a Particular Communication Style? International Journal Of Social Science And Humanities, 2 (1), 2166-7721. Retrieved from http://www.researchpub.org/journal/ijssh/ijssh.html

Gardner, M. (2015). Reading and Reasoning with Knowledge Graphs. PhD Thesis.

Jeannotte, D., \& Kieran, C. (2017). A conceptual model of mathematical reasoning for school mathematics. Educational Studies in Mathematics. https://doi.org/10.1007/s10649-017-9761-8

J. Allen, \& S. Brock. Health care communication using personality type: patients are different! Philadelphia: Taylor \& Francis, 2000.

Kayser, D. (2010). The Place of Logic in Reasoning. Logica Universalis. https://doi.org/10.1007/s11787-010-0017-y

Kusmaryono, I., Suyitno, H., Dwijanto, D., \& Dwidayati, N. (2018a). Analysis of Abstract Reasoning From Grade 8 Students in Mathematical Problem Solving With Solo Taxonomy Guide. Infinity Journal, 7(2), 69. https://doi.org/10.22460/infinity.v7i2.p69-82 
Kusmaryono, I., Suyitno, H., Dwijanto, D., \& Dwidayati, N. (2018b). Analysis of Abstract Reasoning From Grade 8 Students in Mathematical Problem Solving With Solo Taxonomy Guide. Infinity Journal, 7(2), 69. https://doi.org/10.22460/infinity.v7i2.p69-82

Kuntjojo. 2009. PSIKOLOGI KEPRIBADIAN. Kediri: Penerbit : PENDIDIKAN BIMBINGAN DAN KONSELING UNIVERSITAS NUSANTARA PGRI KEDIRI

Littauer.2008.Personality Plus. Jakarta :Penerbit : Kharisma

Lithner, J. (2008). A Research Framework for Creative and Imitative Reasoning. Education Study Mathematic, (67), 255- 276.

Nurdin,2015.Pengaruh Kemanpuan Verbal Dan Penyesuaian Diri Terhadap Prestasi Belajar matematika Siswa Berkepribadian Sanguinis Dan Koleris Di MAN Baraka Enrekang.PANRITA 10(3).565-571.

Nurdin,2016.Alur Berpikir Mahasiswa Koleris Dalam Memecahkan Masalah Matematika Berdasarkan Langkah Polya. JURNAL PENDIDIKAN BIHARUL ULUM MA‘ARIF 01(01) 14-19.

Nurdin,2019: DERIVATIVE of THE PROPERTIES OF PERSONALITY IN SOLVING MATHEMATICAL PROBLEMS, national seminar proceedings, volume 4 . nomor 1 ,

Nurdin,2018 .Turunan Sifat-sifat Kepribadian Sanguinis Dan Mekanisme Dalam Pemecahan Masalah Matematika.Prosiding Seminar Nasional UNIVERSITAS COKROAMINOTO PALOPO 4 (1).78-86 .

Richard C. Emanuel Do Certain Personality Types Have a Particular Communication Style? ,INTERNATIONAL JOURNAL OF SOCIAL SCIENCE AND HUMANITIES VOL.2 NO.1 APRIL $2013 \quad$ ISSN 2166-7721 http://www.researchpub.org/journal/ijssh/ijssh.html

Paxton, J. M., Ungar, L., \& Greene, J. D. (2012). Reflection and reasoning in moral judgment. Cognitive Science. https://doi.org/10.1111/j.1551-6709.2011.01210.x

Sjarkawi. 2009. Pembentukan Kepribadian Anak. Jakarta: PT. Bumi Aksara.

S. Leung, \& M. Bond. "Interpersonal communication and personality: Self and other perspectives," Asian Journal of Social Psychology, vol. 4, pp. 69-86, 2001.

Suryabrata, Sumardi. 2012. Psikologi Pendidikan. Jakarta: PT Rajagrafindo

Zeithamova, D., Schlichting, M. L., \& Preston, A. R. (2012). The hippocampus and inferential reasoning: Building memories to navigate future decisions. Frontiers in Human Neuroscience. https://doi.org/10.3389/fnhum.2012.00070 